Technical schools should make every endeavor to develop men who are capable of advancing the art and who are not mere followers of "best practise," an end that may be secured by the more general use of books of this type. The reviewer agrees thoroughly with the author's point of view and in general with his methods; minor criticisms seem unnecessary. The lack of reference to the work of others is noticed. The abbreviation of "logarithm" to $l n$, in the same font as is used for expressing quantities, seems undesirable; thus, $\ln i$ is not recognized at once as the familiar $\log i$. Some statements in regard to units might well be qualified by the insertion of "sometimes used" or of some similar phrase; since, for example, no electrical congress has recommended the "gilbert" or the "abvolt," objection may be taken to the statements that the C.G.S. unit of magnetic potential difference is the "gilbert" ( $p$. 92) and the C.G.S. unit of electric potential difference is the "abvolt." In general, however, the phraseology is precise.

\section{Frederick Bedell}

Electro-Analysis. By Edgar F. SMith, Professor of Chemisty and Provost, University of Pennsylvania. Fifth edition. Philadelphia, P. Blakiston's Son \& Co. 1911. 12mo. 332 pages, 46 illustrations, flexible leather binding. Price ?

The revised and enlarged edition of this attractive and useful book contains, as new material, the essentials of all that has appeared upon electro-analysis during the past four years. The author particularly emphasizes his continued success in using the mercury cup and his conviction of its wide utility in electrolytic analysis. To those unfamiliar with the previous editions it may be said that the work contains practically everything of value extant in electro-analysis, presented in most attractive and available form, and that possibly half of the whole subject matter is the direct work of Dr. Smith and his students and assistants. It is quite pertinent to call attention to the fact that many of the methods of exact quantitative separation and precipitation used in electro-analysis are borrowed from and constitute modifications of industrially applied processes; this is especially true of the mercury cathode methods; reciprocally it is even still more evident that many valuable industrial processes have evolved from the laboratory investigations and the exact manipulations of electro-analysis, and yet more are waiting to be developed. This reciprocal excitation of laboratory and works is a particularly gratifying object lesson in modern scientific and industrial interdependence. We therefore recommend the book most heartily, not only to chemical analysts, but just as strongly to technical electrochemists studying the problems of electrochemistry, both in the research laboratory and in the works.

JOSEPH W. RIGHARDS

\section{THE HABITS OF FLIES OF THE GENUS CORDYLOBIA, PARASITIC ON MAN IN $A F R I C A$}

IN Africa the larvæ of certain flies (Cordylobia) of the family Muscidæ are parasitic under the skin of man and other warm-blooded animals in the same manner as are the larvæ of many of the flies usually grouped together as Estridæ. Until recently the manner in which Cordylobia infected its host was unknown. Independent results have now thrown light on this question.

Monsieur E. Roubaud, in the Comptes Rendus Hebdomadaires des Séances de l'Academie des Sciences of the 23d of October, 1911. presents the results of his studies of the "Ver du Cayor," Cordylobia anthropophaga Blanchard. The larva is found under the skin of man and domestic animals. In the Estridæ, with the forms found in tumors under the skin, two distinct modes of infection of the host are known. In both cases the eggs of the fly are laid upon the host. In one case the newly hatched larvæ penetrate at once to their proper habitat, but in the other the eggs are swallowed by the host and the newly hatched larvæ bury themselves in the tissues of the œsophagus and only reach the surface after protracted wanderings within the body of 
their host. With these facts in mind M. Roubaud experimented upon Cordylobia. $\mathrm{He}$ found that eggs placed directly upon the skin do not result in the infection of the animals. In the same way his experiments indicated that where eggs were swallowed by animals no infection followed. His experiments with a third method proved successful. Fifteen small larvæ were taken immediately upon the hatching of the eggs and were placed upon a light layer of sand in a large vessel. A guinea pig was shut up in the vessel for twenty hours and then taken out and placed in a wire cage. The result was that three days afterwards six tumors were found on the under side of the body, upon the muzzle and near the anus, each one containing a rapidly developing larva. His experiments indicate, therefore, that infestation is accomplished exclusively by the direct and active penetration of young larvæ hatched elsewhere. He followed day by day the evolution of the larva and describes the successive stages, which occupy only a week. He believes that Europeans are only accidental hosts of this parasite, but that with the natives who sleep on the ground the infection is naturally much more easy. The investigations were made in the laboratory at Bamako.

Of equal interest are the observations of Herbert von Pelser-Berensberg ("Societas entomologica," Vol. 26, p. 34, July 29, 1911) on Cordylobia rodhaini Gedoelst. It had been supposed that uncleanly habits led to infection, but it was found that those persons who bathed most frequently were most subject to infection and the inference was that the eggs were laid upon the exposed body. Keeping eggs under a watch-glass bound to his arm, von Pelser-Berensberg found that the newly hatched larvæ, while they gnawed the skin, did not succeed in penetrating. Later he solved the problem by direct observation. While bathing he noticed that certain flies were attracted to the clothing which he had spread out on bushes, in the sun, to dry off the perspiration. He found that these flies were Cordylobia and that they had glued about twenty eggs to his underclothing. As an experiment he continued to wear the clothing.
Examination at the end of the first day showed that the eggs were intact, but on the second day they had hatched. Search with a lens upon the skin revealed some minute red spots and beneath these were the young larvæ, about $.5 \mathrm{~mm}$. long.

Frederick KNaB

\section{THE NATIONAL ACADEMT OF SCIENCES}

THE scientific program of the National Academy of Sciences, which met at Washington on April 16, 17 and 18, was as follows:

George E. Hale: "The New Tower Telescope of the Mount Wilson Solar Observatory."'

W. W. Campbell: "Radial Velocities of 213 Brighter Class A Stars." "Radial Velocities of 190 Brighter Class F Stars.", "Some Characteristics of Stellar Motions.',

W. J. Humphreys (introduced by Cleveland Abbe): "Holes in the Air."

R. A. Harper: "The Organization of the Cell Colony in Pediastrum.", (By title.)

D. H. Campbell: "On the Morphology and Systematic Position of Calycularia radioulosa (Sande Lac) Stephens.", (By title.)

William Trelease: "A Revision of Phoradendron."

H. F. Osborn: “Biological Foundation of Bergson's 'Creative Evolution.',' (By title.)

E. S. Morse: "Biographical Memoir of C. O. Whitman." (By title.)

G. L. Goodale: "Biographical Memoir of Alexander Agassiz." (By title.)

$B y$ invitation of the Council-

Harvey Cushing: "Some Observations on the Functions of the Pituitary Body.",

Jacques Loeb: "The Activation of the Animal Egg from the Physico-chemical Standpoint." (By title.)

J. A. Holmes: "The National Phases of the Mining Industry.",

C. G. Abbot: "The Solar Radiation."

\section{ANNUAL MEETING OF THE AMERICAN FEDERATION OF TEACHERS OF THE MATHEMATICAL AND THE NATURAL SCIENCES}

THE American Federation of Teachers of the Mathematical and the Natural Sciences held its annual meeting at the New Willard Hotel in Washington on December 27. 